\title{
Nutritional status of yellow passion fruit fertilized with phosphorus sources and doses
}

Gaudêncio Pereira dos Santos ${ }^{1}$, Lourival Ferreira Cavalcante ${ }^{1}$, José Adeilson Medeiros do Nascimento $^{2}$, Antonio João de Lima Neto ${ }^{3 *}$. Sherly Aparecida da Silva Medeiros ${ }^{1}$, Ítalo Herbert Lucena Cavalcante ${ }^{4}$

${ }^{1}$ Universidade Federal da Paraiba/Centro de Ciências Agrárias, Areia, Paraíba, Brazil. ${ }^{2}$ Instituto Federal de Educação, Ciência e Tecnologia do Ceará, Tianguá, Ceará, Brazil. ${ }^{3}$ Departamento de Fitotecnia, Universidade Federal de Viçosa, Av. Peter Henry Rolfs, s/n, Viçosa, Minas Gerais, Brazil. ${ }^{4}$ Universidade Federal do Vale do São Francisco/Centro de Ciências Agrárias, Petrolina, Pernambuco, Brazil.

*Corresponding author:antonio.joao@ufv.br

\begin{abstract}
Phosphorus is important to plant growth due to its storage and energy transference processes and its involvement in the active absorption of other nutrients. The aim of this study was to evaluate the nutritional status of yellow passion fruit plants under fertilization from different $\mathrm{P}_{2} \mathrm{O}_{5}$ sources and rates. Treatments were distributed in randomized blocks in a $2 \times 5$ factorial design, with two phosphorus sources (simple and triple superphosphate) and five $\mathrm{P}_{2} \mathrm{O}_{5}$ doses of $0,12,18,24$ and $30 \mathrm{~g} \mathrm{hole}^{-1}$. A total of two applications were performed at 60 and 120 days after seedling transplanting; $\mathrm{P}_{2} \mathrm{O}_{5}$ doses of $0,24,36,48$ and $60 \mathrm{~g}$ hole $\mathrm{e}^{-1}$ were equivalent to $0,27,40,53$ and $67 \mathrm{~kg} \mathrm{hole}^{-1}$ of $\mathrm{P}_{2} \mathrm{O}_{5}$ from each superphosphate source, respectively. When the orchard was in fructification, 150 days after seedling transplanting, individual leaf samples were harvested from the median branches of the plants in each parcel in order to evaluate $\mathrm{N}, \mathrm{P}, \mathrm{K}, \mathrm{Ca}, \mathrm{Mg}, \mathrm{S}, \mathrm{B}, \mathrm{Cu}, \mathrm{Fe}, \mathrm{Mn}, \mathrm{Zn}$ and $\mathrm{Na}$ contents. The phosphate fertilization promoted adequate nutrition for passion fruit plants of $\mathrm{N}, \mathrm{P}, \mathrm{K}, \mathrm{Mg}$ and $\mathrm{S}$, independent of the source provided, but adequate $\mathrm{Ca}$ only for doses up to $36 \mathrm{~g}_{\text {hole }}^{-1}$ of $\mathrm{P}_{2} \mathrm{O}_{5}$. Plants were impaired in $\mathrm{B}, \mathrm{Cu}, \mathrm{Fe}$ and $\mathrm{Mn}$, except for $\mathrm{Fe}$ in those not fertilized with $\mathrm{P}_{2} \mathrm{O}_{5}$ and those treated with 24 and $36 \mathrm{~g} \mathrm{hole}^{-1}$ of $\mathrm{P}_{2} \mathrm{O}_{5}$ in simple superphosphate form. Considering the adequate nutritional value of passion fruit, it is recommended to fertilize with 36 g hole $^{-1}$ year ${ }^{-1}$ of $\mathrm{P}_{2} \mathrm{O}_{5}$, whether simple or triple superphosphate.
\end{abstract}

Keywords: Passiflora edulis Sims., superphosphates, mineral nutrition 


\section{Introduction}

The yellow passion fruit (Passiflora edulis Sims.) is commercially grown throughout Brazil and in both tropical and subtropical regions due to soil and climatic conditions, which favour its development (Silva-Matos et al., 2016). This crop occupies a relevant place in tropical fruit farming and is considered a promising agricultural alternative for small estates due to its rapid economic return and year-round revenue (Meletti, 2011).

The field explored by the passion fruit has been increasing over the last several years; however, because its productive potential may reach $50 \mathrm{t} \mathrm{ha}^{-1}$, the mean productivity is considered low, approximately $14 \mathrm{t}$ ha $^{-1}$ (Meletti, 2011). Thus, despite advances in agricultural research and investments in new genotypes, the productive channel of this fruit tree still has issues that, in part, may be related to fertilization inadequacy and plant nutrition, resulting in low productivity.

Phosphorus is a crucial nutrient in plant metabolism, playing an important role in storage and energy transference, respiration and the photosynthetic process (Marschner, 2012). Yellow passion fruit requirements for phosphorus are relatively low compared to those for $\mathrm{N}$ and $\mathrm{K}$, being the fourth-most accumulated nutrient in plant leaf dry mass (Malavolta et al., 1997; Carvalho et al., 2011; Cavalcante et al., 2012). However, it is an element supplied in large quantities in fertilization in Brazil, because of its high fixation capacity in tropical soils.

Phosphorus fertilization is essential for passion fruit plants, as research results indicate that adequate dose supplies stimulate plant growth, thus improving nutritional status during the seedling (Prado et al., 2005; Vitorazi Filho et al., 2012; Silva et al., 2015) and mature stages (Borges et al. 2002a; Kondo and Higuchi, 2013). However, despite the importance of this macronutrient in plant nutrition and the microbiological effects on its availability (Martínez et al., 2015), there is a lack of recent information about phosphorus's effects on passion fruit nutritional status during the productive stage and in field conditions.

In addition to adequate doses, one must consider, at the moment of fertilization, the source of phosphorus that will be used, as this influences the plants' nutritional supplies and the economic viability for the farmer (Barbosa et al., 2015). Market sources differ in their $\mathrm{P}$ contents and in other nutrients such as $\mathrm{Ca}$ and $\mathrm{S}$ as well as solubility, access and market prices. Source evaluation and phosphorus dose studies are crucial for economically viable harvest of yellow passion fruit.

The aim of this study was to evaluate the nutritional status of yellow passion fruit plants under fertilization with different sources and doses of phosphorus.

\section{Materials and Methods}

\subsection{Site description}

Growth activities were carried out from March 2010 to July 2011 (Santos et al., 2014) and those related to plant nutritional status from March to July 2010. The experiments were conducted in Remígio (6 63 '00"S / 36 $02^{\circ} 00^{\prime}$ 'W, $470 \mathrm{~m}$ ), in the Curimataú Ocidental semiarid region, Paraíba state, Brazil. The climate is As'-type according to Köppen's classification (Alvares et al., 2013), warm and dry. The rainfall recorded from January to July 2010 was $576 \mathrm{~mm}$, the mean air temperature was $24.5^{\circ} \mathrm{C}$ and the average relative humidity was $81 \%$.

The soil is classified according to Embrapa (2013) as Dystrophic Typic Quartzipsamment (Entisol), with a declivity of $4 \%$. Before the application of the treatments, a chemical and physical characterization 
was completed in soil samples at a depth of $0-40 \mathrm{~cm}$ (Table 1) according to the suggested methodologies of Embrapa (2011).

The yellow passion fruit (Passiflora edulis Sims) cV IAC $273 / 277+275$ was cultivated in a $3 \times 3$ spacing, using a simple espalier system for plant support, with flat wire $\mathrm{n}^{\mathrm{o}} 12$, built to a height of $2.2 \mathrm{~m}$, at the apex of the cuttings. The planting pits were dug in a 40 $\times 40 \times 40 \mathrm{~cm}$ dimension and prepared with $10 \mathrm{~L}$ of bovine manure with a $\mathrm{C} / \mathrm{N}$ ratio of $18: 1$ (Table 1) and $12 \mathrm{~g}$ of dolomitic limestone (PRNT 80\%, 26\% of $\mathrm{CaO}$ and $14 \%$ of $\mathrm{MgO}$ ) to enhance the soil base saturation percentage to $70 \%$, according to Borges et al. (2002b).

Table 1. Soil chemical and physical characterization for fertility and fertilization at a depth of $0-40 \mathrm{~cm}$ and chemical attributes of bovine manure used in the experiment.

\begin{tabular}{lcccc}
\hline Chemical attributes & Soil & Manure & Physical attributes & Soil \\
\hline $\mathrm{pH}$ in water $(1: 2.5)$ & 5.70 & 8.64 & Sand $\left(\mathrm{g} \mathrm{kg}^{-1}\right)$ & 925 \\
$\mathrm{P}\left(\mathrm{mg} \mathrm{dm}^{-3}\right)$ & 4.50 & 36.11 & Silt $\left(\mathrm{g} \mathrm{kg}^{-1}\right)$ & 54 \\
$\mathrm{~K}^{+}\left(\mathrm{cmol}_{\mathrm{c}} \mathrm{dm}^{-3}\right)$ & 0.12 & 92.3 & Clay $\left(\mathrm{g} \mathrm{kg}^{-1}\right)$ & 21 \\
$\mathrm{Na}^{+}\left(\mathrm{cmol}_{\mathrm{c}} \mathrm{dm}^{-3}\right)$ & 0.10 & 3.86 & Clay dispersed in water $\left(\mathrm{g} \mathrm{kg}^{-1}\right)$ & 10.00 \\
$\mathrm{Ca}^{2+}\left(\mathrm{cmol}_{\mathrm{c}} \mathrm{dm}^{-3}\right)$ & 0.50 & 5.40 & Index of flocculation $(\%)$ & 51.00 \\
$\mathrm{Mg}^{2+}\left(\mathrm{cmol}_{\mathrm{c}} \mathrm{dm}^{-3}\right)$ & 0.75 & 4.50 & Soil bulk density $\left(\mathrm{g} \mathrm{cm}^{3}\right)$ & 1.50 \\
$\mathrm{H}^{+}+\mathrm{Al}^{3+}\left(\mathrm{cmol}_{\mathrm{c}} \mathrm{dm}^{-3}\right)$ & 1.46 & - & Soil particle density $\left(\mathrm{g} \mathrm{cm}^{3}\right)$ & 2.70 \\
$\mathrm{C}\left(\mathrm{g} \mathrm{dm}^{-3}\right)$ & 0.19 & 35.23 & Total porosity $\left(\mathrm{m}^{3} \mathrm{~m}^{-3}\right)$ & 0.50 \\
$\mathrm{OM}\left(\mathrm{g} \mathrm{dm}^{-3}\right)$ & 3.30 & - & Micro porosity $\left(\mathrm{m}^{3} \mathrm{~m}^{3}\right)$ & 0.04 \\
$\mathrm{SB}\left(\mathrm{cmol}_{\mathrm{c}} \mathrm{dm}^{-3}\right)$ & 1.37 & - & Macro porosity $\left(\mathrm{m}^{3} \mathrm{~m}^{3}\right)$ & 0.42 \\
$\mathrm{CEC}\left(\mathrm{cmol}_{\mathrm{c}} \mathrm{dm}^{-3}\right)$ & 2.83 & - & Water content FC $\left(\mathrm{g} \mathrm{kg}^{-1}\right)$ & 46.00 \\
$\mathrm{~V}(\%)$ & 48.4 & - & Water content $\mathrm{PMP}\left(\mathrm{g} \mathrm{kg}^{-1}\right)$ & 13.70 \\
\hline *LR $\left(\mathrm{g} \mathrm{hole}^{-1}\right)$ & 140 & - & Texture & Sandy \\
\hline
\end{tabular}

$\mathrm{P}, \mathrm{K}$ and $\mathrm{Na}^{+}=$Mehlich 1 extractor; $\mathrm{Al}^{3+}, \mathrm{Ca}^{2+}, \mathrm{Mg}^{2+}=$ extractor $\mathrm{KCl} 1 \mathrm{M} ; \mathrm{C}=$ Organic carbon; OM= Organic matter in the soil by oxidation with potassium permanganate; $\mathrm{SB}=\mathrm{Sum}$ of bases $\left(\mathrm{Na}^{+}+\mathrm{K}^{+}+\mathrm{Ca}^{2+}+\mathrm{Mg}^{2+}\right)$; $\mathrm{CEC}=\mathrm{Cation}$ exchange capacity $=$ $\mathrm{SB}+\left(\mathrm{H}^{+}+\mathrm{Al}^{3+}\right) ; \mathrm{V}=$ Exchangeable base saturation $(100 * \mathrm{SB} / \mathrm{CEC}) ; \mathrm{LR}=$ Liming requirement.

\subsection{Experimental design and field management}

Treatments were distributed in randomized blocks, with three replicates and 12 plants per parcel, in a $2 \times$ 5 factorial design, with two phosphates sources (simple superphosphate - $18 \% \mathrm{P}_{2} \mathrm{O}_{5}, 18$ in $20 \% \mathrm{Ca}, 12 \%$ $\mathrm{S}$ and triple superphosphate $-42 \% \mathrm{P}_{2} \mathrm{O}_{5}, 12$ in $14 \%$ $\mathrm{Ca}$ ), in doses of $0,12,18,24$ and $30 \mathrm{~g}_{\text {hole }}^{-1}$ of $\mathrm{P}_{2} \mathrm{O}_{5}$ in two equal applications at 60 and 120 days after seedling transplantation in the field, totalling $0,24,36,48$ and $60 \mathrm{~g} \mathrm{hole}^{-1}$ of $\mathrm{P}_{2} \mathrm{O}_{5}$ broadcast supplied in a $0.5 \mathrm{~m}^{2}$ area within a $40 \mathrm{~cm}$ radius from the plant stalk, where there is the highest proportion of active roots (Sousa et al., 2002). The fertilizer doses studied were defined according to soil analysis following the recommendations of Ribeiro et al. (1999). 
Fertilization with nitrogen and potassium, before orchard nutritional status determination, was carried out in the same area $\left(0.5 \mathrm{~m}^{2}\right)$ as phosphate fertilization, in three applications under a proportion of $1 \mathrm{~N}: 1 \mathrm{~K}_{2} \mathrm{O}$, assuming as sources, respectively, urea $(44 \% \mathrm{~N})$ and potassium chlorite $\left(58 \% \mathrm{~K}_{2} \mathrm{O}\right)$. After 60 and 90 days, respectively, $10 \mathrm{~g}$ of $\mathrm{N}$ and $10 \mathrm{~g}$ of $\mathrm{K}_{2} \mathrm{O}$ were supplied, and $15 \mathrm{~g}$ of $\mathrm{N}$ and $15 \mathrm{~g}$ of $\mathrm{K}_{2} \mathrm{O}$ were supplied at the beginning of flowering 120 days after planting according to Borges et al. (2002b). These values correspond to the application of $35 \mathrm{~g} \mathrm{plant}^{-1}$ of $\mathrm{N}$ and $\mathrm{K}_{2} \mathrm{O}$, corresponding to 80 and $60 \mathrm{~g} \mathrm{plant}^{-1}$ of urea and potassium chlorite, referring to 90 and $67 \mathrm{~kg} \mathrm{ha}^{-1}$ of the mineral fertilizer, respectively, before plant fructification.

Irrigation was performed using a locally applied dripping method, with two emitters under a flow rate of $3.75 \mathrm{~L} \mathrm{~h}^{-1}$ at $20 \mathrm{~cm}$ from plant stalks, based on the crop evapotranspiration (ETc) estimated with reference to the evapotranspiration product $\left(\mathrm{ET}_{0}\right)$ of the crop coefficient of 1.2 (Souza et al., 2009), during the flowering stage at the end of harvesting. The $\mathrm{ET}_{0}(\mathrm{ECA} \times$ 0.75 ) was obtained based on measured evaporation in a Class A pan installed at the experimental site.

At 150 days after seedling transplantation, when the orchard was fruiting, samples were individually collec- ted following the instructions of Malavolta et al. (1997), i.e. 48 leaves of healthy median branches ( $4^{\text {th }}$ leaf from branch apex) for each parcel, for evaluation of $\mathrm{N}, \mathrm{P}, \mathrm{K}, \mathrm{Ca}, \mathrm{Mg}, \mathrm{S}, \mathrm{B}, \mathrm{Cu}, \mathrm{Fe}, \mathrm{Mn}, \mathrm{Zn}$ and $\mathrm{Na}$ in plant leaf dry mass, according to the methodology described by Bataglia et al. (1983).

\subsection{Statistical analysis}

The results were submitted to variance analysis using the F-test. The mean values of the $\mathrm{P}_{2} \mathrm{O}_{5}$ sources were compared using the F-test, which is conclusive for both factors, and the evaluation doses were evaluated by polynomial regression using the Sisvar software (Ferreira, 2014).

\section{Results}

According to variance analysis, among the macronutrients, the $\mathrm{N}$ leaf contents from yellow passion fruit plants were significantly influenced by the isolate action of $\mathrm{P}_{2} \mathrm{O}_{5}$ source and doses; $\mathrm{P}$ and $\mathrm{K}$ contents were influenced by the $\mathrm{P}_{2} \mathrm{O}_{5}$ doses and $\mathrm{Ca}, \mathrm{Mg}$ and $\mathrm{S}$ responded to the interaction source $\mathrm{x}$ dose of $\mathrm{P}_{2} \mathrm{O}_{5}$ (Table 2).

Table 2. Overview of variance analysis by mean square regarding values of nitrogen, phosphorus, potassium, calcium, magnesium and sulphur contents in leaf dry mass of yellow passion fuits plants exposed to $\mathrm{P}_{2} \mathrm{O}_{5}$ sources and doses.

\begin{tabular}{lccccccc}
\hline \multirow{2}{*}{ Source of variation } & \multirow{2}{*}{$\mathrm{DF}$} & \multicolumn{7}{c}{ Mean Square } \\
\cline { 3 - 8 } & & $\mathrm{N}$ & $\mathrm{P}$ & $\mathrm{K}$ & $\mathrm{Ca}$ & $\mathrm{Mg}$ & $\mathrm{S}$ \\
\hline Blocks & 2 & $17.5^{\mathrm{ns}}$ & $0.1^{\mathrm{ns}}$ & $45.7^{*}$ & $6.5^{\mathrm{ns}}$ & $0.4^{\mathrm{ns}}$ & $0.2^{\mathrm{ns}}$ \\
Sources (S) & 1 & $120.0^{*}$ & $0.1^{\mathrm{ns}}$ & $13.3^{\mathrm{ns}}$ & $108.3^{* *}$ & $53.3^{* *}$ & $13.3^{* *}$ \\
Doses (D) & 4 & $101.5^{* *}$ & $5.7^{* *}$ & $57.8^{* *}$ & $4.6^{\mathrm{ns}}$ & $2.3^{* *}$ & $9.5^{* *}$ \\
$\mathrm{~S} \times \mathrm{D}$ & 4 & $9.7^{\mathrm{ns}}$ & $0.1^{\mathrm{ns}}$ & $1.1^{\mathrm{ns}}$ & $11.0^{*}$ & $6.4^{* *}$ & $2.1^{* *}$ \\
Residue & 18 & 279.0 & 0.3 & 11.2 & 3.0 & 0.5 & 0.2 \\
$\mathrm{CV}(\%)$ & & 9.0 & 15.5 & 9.4 & 10.5 & 9.2 & 11.5 \\
\hline
\end{tabular}

$\mathrm{DF}=$ Degrees of freedom; ns $=$ Not significant; $*$ and $* *$, respectively, represent $p<0.05$ and $p<0.01$; CV $=$ Coefficient of variation. 
The leaf content of $\mathrm{N}$ was significantly higher in plants where the $\mathrm{P}_{2} \mathrm{O}_{5}$ was supplied as triple superphosphate, compared to that of those treated with simple superphosphate (Figure 1A).
The increase in $\mathrm{P}_{2} \mathrm{O}_{5}$ dose, independently of the source used, enhanced $\mathrm{N}$ leaf content up to a maximum value of $47.0 \mathrm{~g} \mathrm{~kg}^{-1}$ for the $34.1 \mathrm{~g} \mathrm{hole}^{-1} \mathrm{P}_{2} \mathrm{O}_{5}$ dose (Figure 1B).
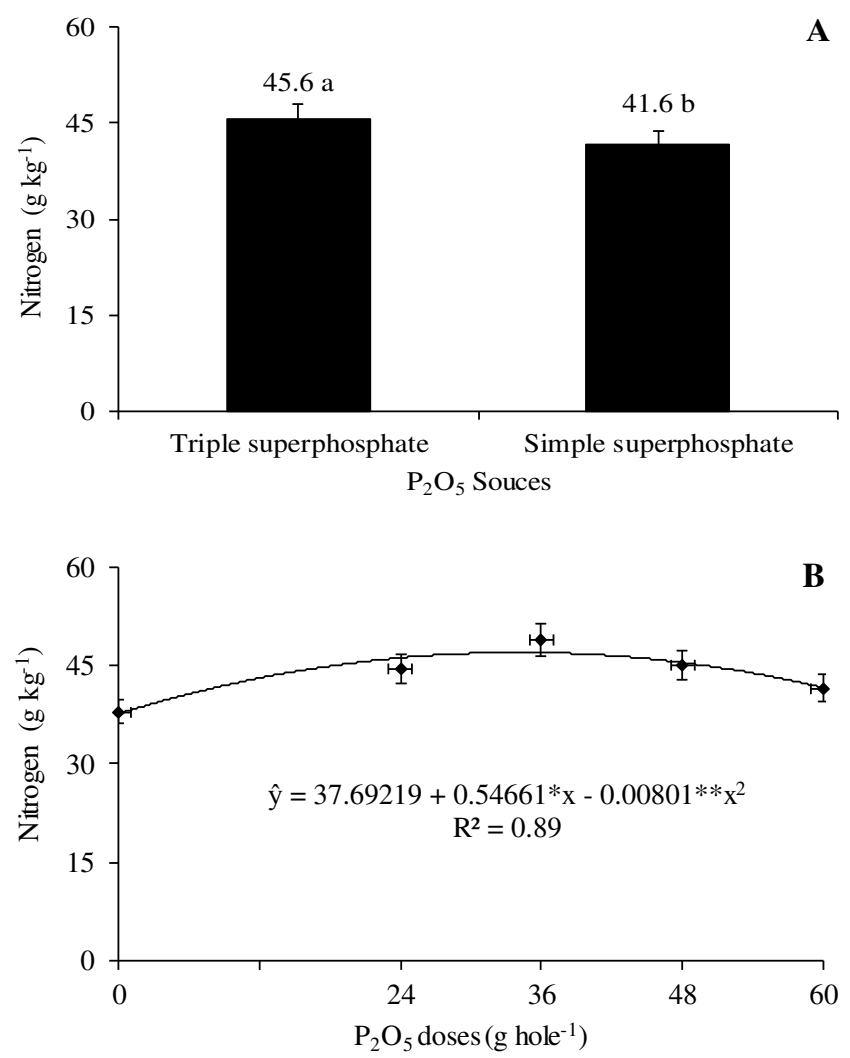

Figure 1. Leaf content of nitrogen in yellow passion fruit plants as a function of sources (A) and doses (B) of $\mathrm{P}_{2} \mathrm{O}_{5}$.

In relation to $\mathrm{P}$ leaf contents, it is possible to infer that independently of the $\mathrm{P}$ source, the $\mathrm{P}$ leaf content was enhanced up to $4.2 \mathrm{~g} \mathrm{~kg}^{-1}$ for the dose of $36.9 \mathrm{~g}$ hole ${ }^{-1}$ of $\mathrm{P}_{2} \mathrm{O}_{5}$ (Figure $2 \mathrm{~A}$ ). The $\mathrm{K}$ leaf content in the passion fruit plants was linearly enhanced with an increase in $\mathrm{P}_{2} \mathrm{O}_{5}$ dose supplied to the soil (Figure 2B). 

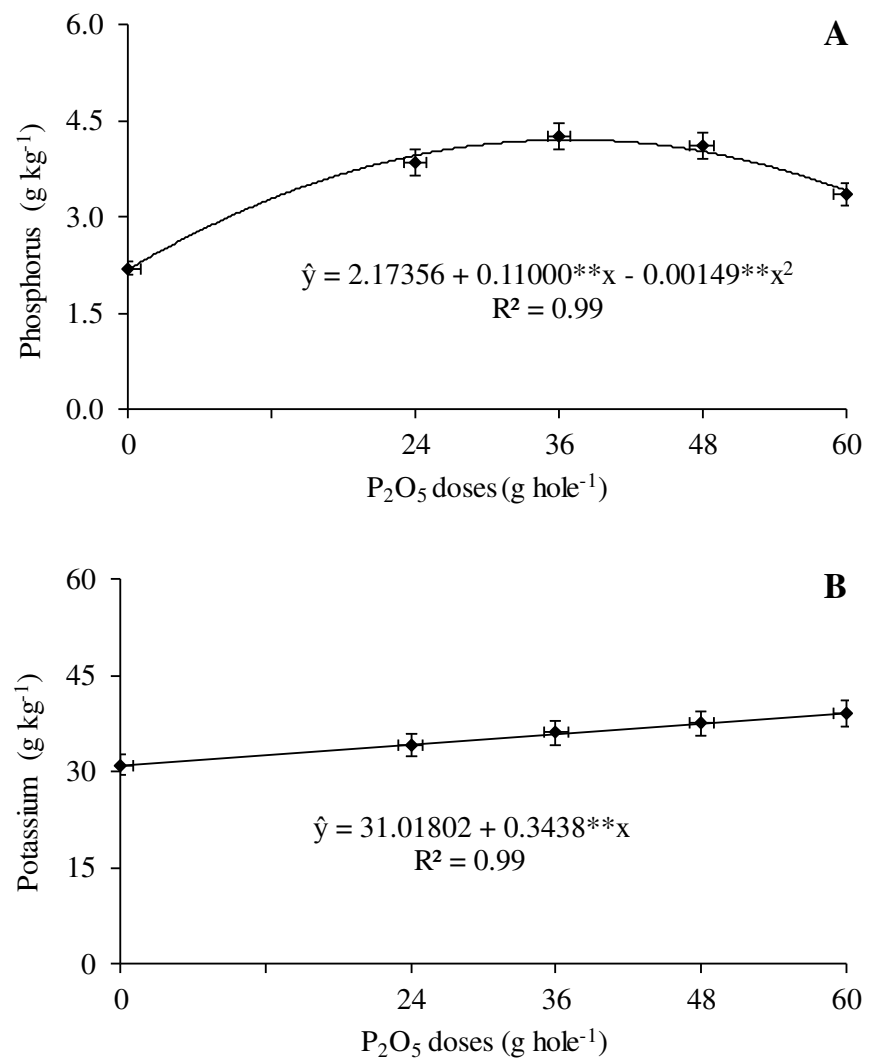

Figure 2. Phosphorus (A) and potassium (B) leaf contents in yellow passion fruit plants as a function of $\mathrm{P}_{2} \mathrm{O}_{5}$ doses.

Regarding $\mathrm{Ca}$, it was observed that plants treated with simple superphosphate had Ca contents linearly enhanced as a function of $\mathrm{P}_{2} \mathrm{O}_{5}$ dose, achieving a maximum Ca value of $20.19 \mathrm{~g} \mathrm{~kg}^{-1}$ with a $\mathrm{P}_{2} \mathrm{O}_{5}$ dose of $60 \mathrm{~g} \mathrm{hole}^{-1}$ (Figure 3A). Indeed, the leaf contents of $\mathrm{Ca}$ in plants treated with simple superphosphate were higher than those treated with triple superphosphate (Figure 3A).

The sources of $\mathrm{P}$ displayed the opposite effects for $\mathrm{Mg}$ leaf contents, as compared to $\mathrm{Ca}$ (Figure 3B).
In plants treated with triple superphosphate, the increase in $\mathrm{P}_{2} \mathrm{O}_{5}$ dose enhanced $\mathrm{Mg}$ contents up to a maximum value of $9.74 \mathrm{~g} \mathrm{~kg}^{-1}$, for the $38.0 \mathrm{~g}$ hole${ }^{1}$ of $\mathrm{P}_{2} \mathrm{O}_{5}$ dose. In contrast, the plants treated with simple superphosphate had $\mathrm{Mg}$ contents that linearly decreased from 7.8 to $4.66 \mathrm{~g} \mathrm{~kg}^{-1}$.

The $\mathrm{S}$ leaf contents were enhanced up to 6.13 and $3.72 \mathrm{~g} \mathrm{~kg}^{-1}$ for $\mathrm{P}_{2} \mathrm{O}_{5}$ doses of 33.68 and $32.29 \mathrm{~g} \mathrm{hole}^{-1}$, using simple and triple superphosphate, respectively (Figure 3C). 

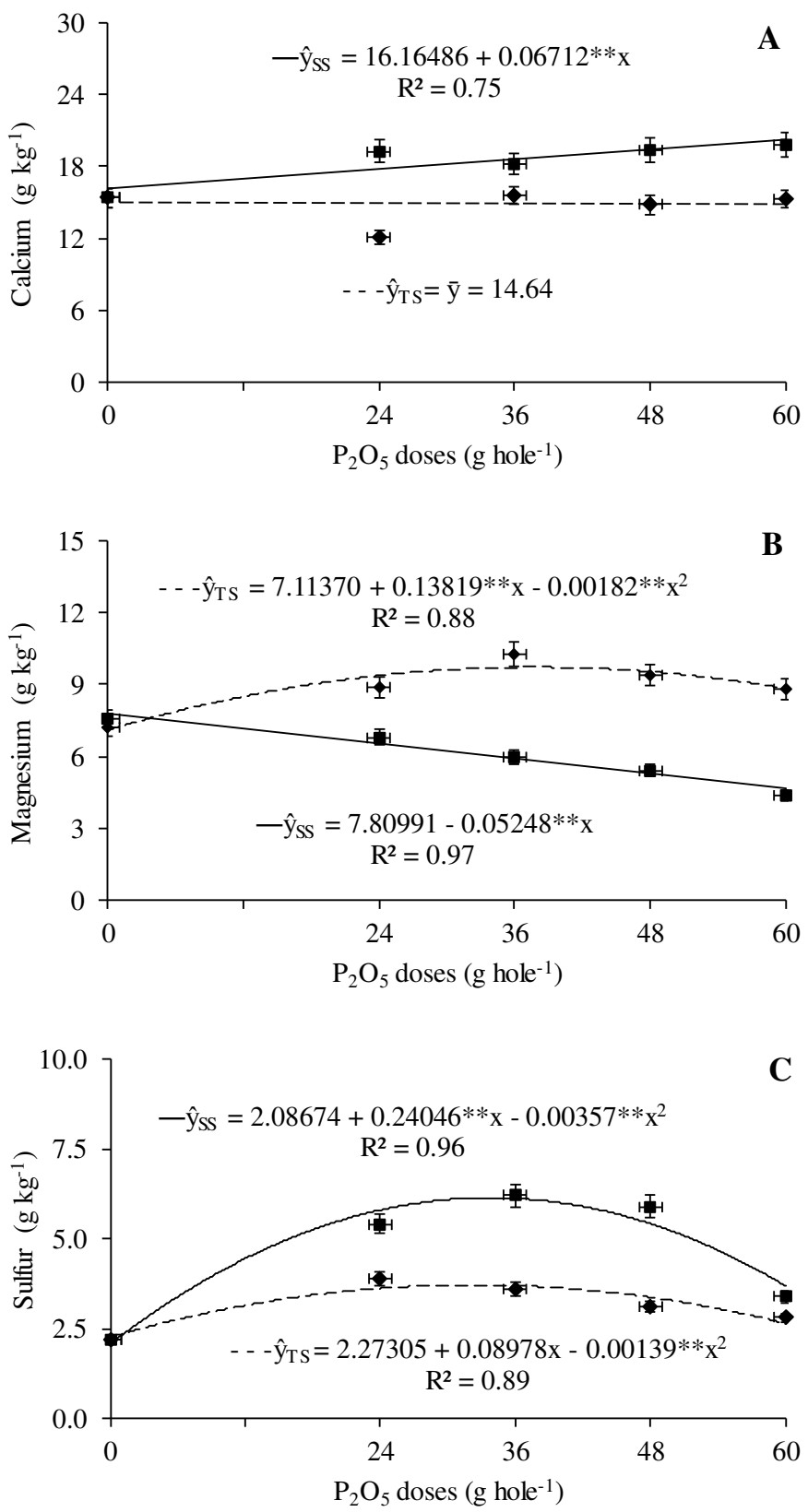

Figure 3. Calcium (A), magnesium (B) and sulfur (C) leaf contents in yellow passion fruit plants as a function of $\mathrm{P}_{2} \mathrm{O}_{5}$ doses of simple superphosphate (-) and triple superphosphate (---). 
Regarding micronutrients, it was verified that only B leaf content significantly responded to the isolated effects of the provided phosphorus sources (Table 3).
The $\mathrm{Cu}, \mathrm{Fe}, \mathrm{Mn}$ and $\mathrm{Zn}$ contents were not significantly affected from either of the sources adopted.

Table 3. Overview of variance analysis by mean square regarding leaf contents of boron, copper, iron, manganese, zinc and sodium contents in leaf dry mass of yellow passion fruit plants exposed to $\mathrm{P}_{2} \mathrm{O}_{5}$ sources and doses.

\begin{tabular}{cccccccc}
\hline \multirow{2}{*}{ Source of variation } & \multirow{2}{*}{ DF } & \multicolumn{6}{c}{ Mean Square } \\
\cline { 3 - 8 } & & $\mathrm{B}$ & $\mathrm{Cu}$ & $\mathrm{Fe}$ & $\mathrm{Mn}$ & $\mathrm{Zn}$ & $\mathrm{Na}$ \\
\hline Blocks & 2 & $23.63^{\text {ns }}$ & $3.10^{\text {ns }}$ & $16.93^{\text {ns }}$ & $16.90^{\text {ns }}$ & $4.90^{\text {ns }}$ & $1.30^{\text {ns }}$ \\
Sources (S) & 1 & $61.63^{* *}$ & $2.70^{\text {ns }}$ & $1400.83^{\text {ns }}$ & $24.30^{\text {ns }}$ & $19.20^{\text {ns }}$ & $235.20^{*}$ \\
Dose (D) & 4 & $31.38^{\text {ns }}$ & $7.95^{\text {ns }}$ & $254.63^{\text {ns }}$ & $106.50^{\text {ns }}$ & $35.50^{\text {ns }}$ & $2942.55^{* *}$ \\
S x D & 4 & $9.88^{\text {ns }}$ & $1.93^{\text {ns }}$ & $227.33^{\text {ns }}$ & $13.80^{\text {ns }}$ & $21.45^{\text {ns }}$ & $2298.4^{* *}$ \\
Residue & 18 & 13.18 & 3.43 & 377.15 & 87.78 & 30.01 & 48.74 \\
CV (\%) & & 12.28 & 27.66 & 17.10 & 13.48 & 15.39 & 10.33 \\
\hline
\end{tabular}

$\mathrm{DF}=$ Degrees of freedom; $\mathrm{ns}=$ Not significant; $*$ and $* *$, respectively, represent $p<0.05$ and $p<0.01 ; \mathrm{CV}=$ Coefficient of variation.

The B leaf contents were higher in yellow passion fruit plants fertilized with simple superphosphate (Figure 4A).

As seen in Table 4, the $\mathrm{Cu}$ leaf contents $\left(6-9 \mathrm{mg} \mathrm{kg}^{-1}\right.$ for simple superphosphate and 5-8 $\mathrm{mg} \mathrm{kg}^{-1}$ for triple superphosphate) and $\mathrm{Mn}$ leaf contents (62-76 mg $\mathrm{kg}^{-1}$ for simple superphosphate and $66-75 \mathrm{mg} \mathrm{kg}^{-1}$ for triple superphosphate) presented a large range. Additionally, Fe leaf contents ranged from 133 to $127 \mathrm{mg}$ $\mathrm{kg}^{-1}$ for simple superphosphate and from 100 to 121 $\mathrm{mg} \mathrm{kg}^{-1}$ for triple superphosphate, while $\mathrm{Zn}$ leaf contents ranged from 32-39 $\mathrm{mg} \mathrm{kg}^{-1}$ (simple superphos- phate) and 32-40 $\mathrm{mg} \mathrm{kg}^{-1}$ (triple superphosphate). The yellow passion fruit plants subjected to a $\mathrm{P}$ supply, in a triple superphosphate form, had Na leaf contents enhanced linearly, with a maximum value $107.3 \mathrm{mg} \mathrm{kg}^{-1}$ for a $\mathrm{P}_{2} \mathrm{O}_{5}$ dose of $60 \mathrm{~g} \mathrm{hole}^{-1}$ (Figure 4B). Moreover, the Na contents were enhanced up to $85.4 \mathrm{mg} \mathrm{kg}^{-1}$, with the increase in simple superphosphate form up to an estimated maximum $\mathrm{P}_{2} \mathrm{O}_{5}$ dose of $32.7 \mathrm{~g} \mathrm{hole}^{-1}$. Indeed, plants treated with simple superphosphate presented lower $\mathrm{Na}$ leaf content compared to those fertilized using triple superphosphate. 


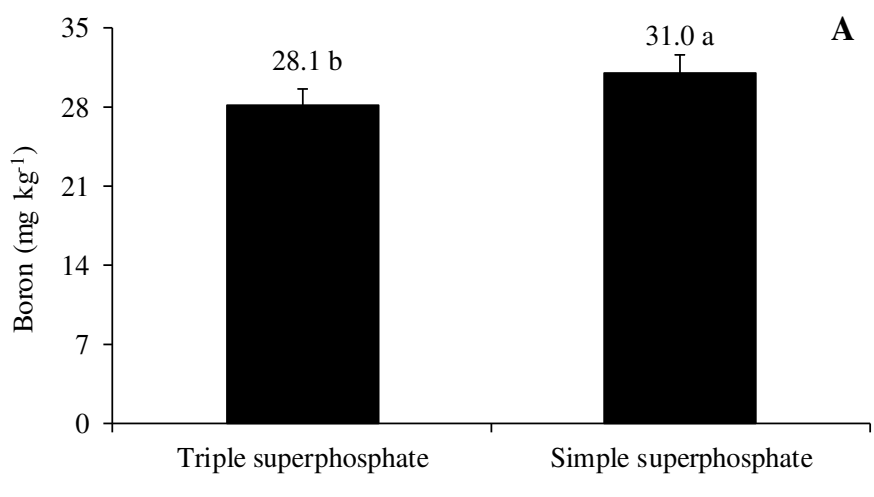

$\mathrm{P}_{2} \mathrm{O}_{5}$ Soucers

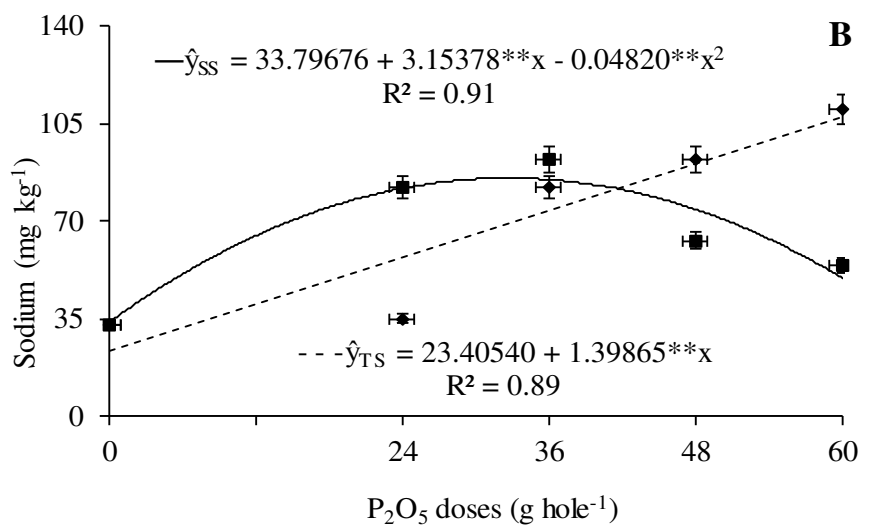

Figure 4. Boron leaf contents (A) as a function of $\mathrm{P}_{2} \mathrm{O}_{5}$ sources and sodium leaf contents (B) of yellow passion fruit as a function of $\mathrm{P}_{2} \mathrm{O}_{5}$ doses of simple superphosphate (-) and triple superphosphate (---).

Table 4. Mean contents of copper, iron, manganese and zinc in yellow passion fruit plant leaf dry mass exposed to $\mathrm{P}_{2} \mathrm{O}_{5}$ sources and doses.

\begin{tabular}{|c|c|c|c|c|c|c|c|c|}
\hline \multirow{2}{*}{$\mathrm{P}_{2} \mathrm{O}_{5}$ doses } & \multicolumn{2}{|c|}{$\mathrm{Cu}$} & \multicolumn{2}{|c|}{$\mathrm{Fe}$} & \multicolumn{2}{|c|}{$\mathrm{Mn}$} & \multicolumn{2}{|c|}{$\mathrm{Zn}$} \\
\hline & SS & TS & SS & TS & SS & TS & SS & TS \\
\hline $\mathrm{g} \mathrm{hole}^{-1}$ & $\cdots$ & $-\cdots$ & $-\cdots$ & $--m s$ & $5^{-1}-$ & 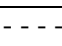 & $-\ldots$ & $\cdots$ \\
\hline 0 & $7^{\mathrm{ns}}$ & $7^{\mathrm{ns}}$ & $121^{\mathrm{ns}}$ & $121^{\mathrm{ns}}$ & $69^{\text {ns }}$ & $69^{\text {ns }}$ & $32^{\mathrm{ns}}$ & $32^{\mathrm{ns}}$ \\
\hline 24 & 6 & 5 & 124 & 116 & 76 & 75 & 34 & 35 \\
\hline 36 & 6 & 5 & 127 & 113 & 71 & 71 & 39 & 37 \\
\hline 48 & 7 & 8 & 117 & 103 & 65 & 71 & 37 & 38 \\
\hline 60 & 9 & 7 & 113 & 100 & 62 & 66 & 32 & 40 \\
\hline
\end{tabular}

ns = non-significant; $\mathrm{SS}=$ Simple superphosphate; $\mathrm{TS}=$ Triple superphosphate. 


\section{Discussion}

Higher $\mathrm{N}$ leaf content in plants fertilized with triple superphosphate occurred because the higher P concentration in the triple superphosphate has a positive action on $\mathrm{N}$ absorption in photosynthetic reactions and $\mathrm{C}$ metabolism, processes that are fundamental for assimilation and utilization of $\mathrm{N}$ and $\mathrm{P}$ (Malavolta $e t$ al., 1997; Brown et al., 2011).

The increase in $\mathrm{N}$ contents in fertilized plants with $\mathrm{P}$ was also observed by Silva et al. (2015) in wild passion fruit (Passiflora edulis) and by Lemos et al. (2015) in coffee (Coffea arabica) plants. Moreira et al. (2016) attested that fertilization with phosphorus enhanced the nitrogen accumulation in pitaya plants (Hylocereus undatus). According to Brown et al. (2011), there is a strong correlation between $\mathrm{N}$ and $\mathrm{P}$ contents, indicating that these nutrients interact in a synergistic way, where adequate doses of both nutrients promote enhancement of each other's absorption, while inhibition occurs when the nutrients are applied in excessive amounts (Cerutti and Delatorre, 2013). Despite the $\mathrm{N}$ content decrease with application of $\mathrm{P}$ doses higher than the maximum physical efficiency, it was noted that, except in the testing dose, the levels obtained are in range of 40-50 $\mathrm{g} \mathrm{kg}^{-1}$, considered adequate by Malavolta et al. (1997) for the yellow passion fruit (Figure 1B).

Leaf $\mathrm{P}$ content as shown in Figure 2A above $4.2 \mathrm{~g} \mathrm{~kg}^{-1}$ is adequate for a yellow passion fruit crop, since it is within the range of 4-5 $\mathrm{g} \mathrm{kg}^{-1}$ (Malavolta et al., 1997). These results are in accordance with those verified by Brunetto et al. (2015) when attesting that phosphate fertilization enhanced $\mathrm{P}$ content in soil and pear tree leaves (Pyrus communis L.). Moreira et al. (2016) attested that the phosphate fertilization in pitaya plants enhanced $\mathrm{P}$ content and its accumulation in plants.

The leaf $\mathrm{P}$ content reduction in plants submitted to doses greater than $36.9 \mathrm{~g}$ hole $^{-1}$ of $\mathrm{P}_{2} \mathrm{O}_{5}$ is possibly linked to a greater stimulus of biomass production, which may result in dilution of $\mathrm{P}$ content in leaf dry mass. According to Barretti et al. (2008), when a chemical analysis is performed in a shoot, the same dry material quantity is used in all samples, and nutrients are extracted from it; in larger plants, the nutrients are less concentrated due to the greater area, and thus, lower nutrient levels may occur in plants with higher vegetal mass. It is important to note that plant species could present different $P$ strategies to acquire $\mathrm{P}$ from soil, and this is important in defining crop management strategies at improving $\mathrm{P}$ use (Sandaña and Pinochet, 2016), especially for poorly studied species such as passion fruit.

Leaf $\mathrm{K}$ concentration enhancement with higher $\mathrm{P}_{2} \mathrm{O}_{5}$ doses (Figure 2B) was also observed by Prado et al. (2005) in passion fruit seedlings submitted to phosphorus doses, with a verified linear increase in leaf and root content of K. Silva et al. (2015) also attested that phosphate fertilization enhances $\mathrm{K}$ leaf content in larger passion fruit plants.

The presence of $\mathrm{P}$ and $\mathrm{Ca}$ in two sources and $\mathrm{S}$ in simple superphosphate favours root growth, which expand to a greater soil volume, contributing to higher water and nutrient absorption by the plants (Marschner, 2012; Moreira et al., 2016). In contrast, when the Ca ranges from low to adequate concentrations in leaf tissues (condition verified in Figure 3A), it favours $\mathrm{K}$ absorption as a synergistic effect (Malavolta et al., 1997).

Malavolta et al. (1997) attested that K leaf contents between $35-45 \mathrm{~g} \mathrm{~kg}^{-1}$ are adequate for yellow passion fruit growth and production. According to the results herein presented in Figure 2B, for yellow passion fruit plants whose $\mathrm{K}$ content must be greater than $35 \mathrm{~g} \mathrm{~kg}^{-1}$, $\mathrm{P}_{2} \mathrm{O}_{5}$ doses greater than $30 \mathrm{~g}$ hole $\mathrm{e}^{-1}$ would be necessary, independent of the supply source.

The leaf $\mathrm{Ca}$ contents with $\mathrm{P}_{2} \mathrm{O}_{5}$ dose enhancement was a result of the higher input of calcium in the 
soil as a function of higher simple superphosphate doses, which contains more $\mathrm{Ca}$ in its formulation than the triple superphosphate (18-20\%, while triple superphosphate has $12-14 \%$ ). In contrast, the Ca leaf contents in plants treated with triple superphosphate did not adjust to any mathematic model, being represented by the Ca mean value $14.64 \mathrm{~g} \mathrm{~kg}^{-1}$. Similar results were observed by Borges et al. (2002a), Prado et al. (2005) and Neves et al. (2008) in leaf contents of $\mathrm{Ca}$ in passion fruit and umbu (Spondias tuberosa) plants, respectively, under phosphate fertilization, using triple superphosphate doses. The lack of significance reported for $\mathrm{Ca}$ leaf contents should be caused by the high Ca bovine manure value (Table 1) used in the experiment, according to Borges et al. (2002b).

Considering adequate $\mathrm{Ca}$ contents for the passion fruit are between 15-20 $\mathrm{g} \mathrm{kg}^{-1}$ (Malavolta et al., 1997), the plants fertilized with triple superphosphate were properly supplied with this nutrient only for doses up to 36 g hole ${ }^{-1}$ of $\mathrm{P}_{2} \mathrm{O}_{5}$, while all the $\mathrm{P}_{2} \mathrm{O}_{5}$ doses provided by simple superphosphate resulted in adequate supply for plants with $\mathrm{Ca}$. Presumably the $\mathrm{Ca}$ amount provided by the triple superphosphate was not sufficient to supply the plants' requirements for this macronutrient.

The incongruent effects of the different $\mathrm{P}_{2} \mathrm{O}_{5}$ sources on $\mathrm{Mg}$ leaf content differs from Prado et al. (2005) who verified $\mathrm{Mg}$ leaf content enhancement in passion fruit seedlings when doses of simple superphosphate applied to the soil were increased. These effects are also in disagreement with Kondo and Higuchi (2013), who studied different $\mathrm{P}$ doses on plant nutritional status and observed higher Mg leaf content when higher P doses were applied.

The linear reduction and lower $\mathrm{Mg}$ leaf content in plants submitted to simple superphosphate is due to the inhibition of absorption of this element caused by increase in K (Figure 2B) and Ca content (Figure 3A), as these nutrients compete for the same adsorption site in the leaf membranes (Malavolta et al., 1997;
Marschner, 2012), associated to the high Mg of the bovine manure (Borges et al., 2002b) used in the experiment, as can be seen in (Table 1). However, even though it was reduced, the Mg leaf content in plants fertilized with simple superphosphate was higher, in the range of 3-4 $\mathrm{g} \mathrm{kg}^{-1}$, which means that the crop was nutritionally balanced in $\mathrm{Mg}$ (Malavolta et al., 1997). The maximum $\mathrm{Mg}$ level obtained with the maximum physical efficiency doses of triple superphosphate is two-fold that of $4.0 \mathrm{~g} \mathrm{~kg}^{-1}$, considered as a limit value of adequacy. Because the initial content of this element in soil is considered a mean (Table 1), the applied limestone provided $\mathrm{Mg}$ in quantities greater than that deemed adequate for the crop.

As a function of $\mathrm{P}_{2} \mathrm{O}_{5}$ dose, the $\mathrm{S}$ leaf contents increased until reaching a peak (Figure 3C) and then decreased, a tendency that agrees with the results recorded by Miyake et al. (2016) but differs from the results of Prado et al. (2005), who recorded a linear decrease in S content in passion fruit seedlings under triple superphosphate doses. On the other hand, for red alder plants (Alnus rubra), Brown et al. (2011) attested as well that fertilization with triple superphosphate enhanced S leaf content during the first year growing the crop.

The superiority of $\mathrm{S}$ contents in plants fertilized with simple superphosphate is because this input contains $12 \%$ of $\mathrm{S}$ in its composition, which does not occur in triple superphosphate. According to the results, it was verified that independent of source supplied, the maximum contents obtained are greater than 2-3 g $\mathrm{kg}^{-1}$ meaning that the plants were properly supplied with S (Malavolta et al., 1997). Although triple superphosphate does not contain $\mathrm{S}$ in its composition, plants submitted to this treatment were also properly nurtured with $\mathrm{S}$. This nurturing occurs because the manure used in planting pit preparation provides $\mathrm{S}$ for the plants; furthermore, this element may be absorbed in low quantities from the atmosphere by leaf absorption. 
Although there were positive effects of simple superphosphate on B leaf content (Figure 4A), the values observed for both $\mathrm{P}$ sources are well below the $\mathrm{B}$ range of 40-50 mg kg-1, considered adequate for the crop (Malavolta et al., 1997). Prado et al. (2005) attested that enhancement of P supply, in simple superphosphate form, resulted in a decrease in B leaf content for yellow passion fruit seedlings. The $\mathrm{Ca}$ and $\mathrm{Mg}$ of the limestone with the Ca supplied with the $\mathrm{P}$ sources possibly increased the soil $\mathrm{pH}$, impairing $\mathrm{B}$ absorption. In addition, Borges et al. (2002a) evaluated the effect of phosphorus doses (simple superphosphate) on the nutritional status of passion fruit and recorded no effect on B leaf contents.

Although there was a wide range recorded for $\mathrm{Cu}$ and Mn leaf contents (Table 4), all average values are below the limits of 10-20 mg kg-1 and 400-600 mg kg-1 considered adequate for yellow passion fruit, respectively (Malavolta et al., 1997). Regarding Fe, when it is considered that passion fruit plants properly supplied must contain leaf contents between 120-200 mg kg-1, it was observed that plants were also impaired in terms of this micronutrient, except in plants not fertilized with $\mathrm{P}_{2} \mathrm{O}_{5}$ and those treated with 24 and $36 \mathrm{~g}_{\text {hole }}^{-1}$ of $\mathrm{P}_{2} \mathrm{O}_{5}$ in simple superphosphate form.

Low availabilities of micronutrients, associated with high soil $\mathrm{pH}$ due to the lime and calcium provided by the $\mathrm{P}$ sources, may have decreased the absorption of $\mathrm{Cu}, \mathrm{Fe}$ and $\mathrm{Mn}$, resulting in values below the critical limit, impairing the plants (Malavolta et al., 1997). This follows Santin et al. (2013), who concluded that high doses of lime decrease micronutrient absorption by the plants.

Despite not being significantly influenced by the variation in sources, $\mathrm{Zn}$ leaf contents contained in Table 4 are within the range of 25-40 $\mathrm{mg} \mathrm{kg}^{-1}$, considered adequate for the crop by Malavolta et al. (1997). Prado et al. (2005) and Lemos et al. (2015) verified that enhancement in $\mathrm{P}$ supply resulted in low $\mathrm{Zn}$ contents in passion fruit and coffee plants, respectively. According to Malavolta et al. (1997), the higher P absorption by plants may result in lower absorption of other nutrients such as Zn. In contrast, Borges et al. (2002a) in a study performed in a sandy loam soil, recorded no effect of phosphorus doses on $\mathrm{Zn}$ leaf content.

Higher simple superphosphate doses also promoted high Na leaf contents (Figure 4B), a result that is in agreement with Silva et al. (2015), who attested enhancement of $\mathrm{Na}$ leaf contents in wild passion fruit plants fertilized with simple superphosphate. In addition, the higher Na leaf content promoted by triple superphosphate in relation to the simple superphosphate occurred because it contains higher $\mathrm{Ca}$ level in its composition, which favours larger $\mathrm{Na}$ displacement in soil charge sites, resulting in leaching and a decrease in its availability to plants (Leite et al., 2010).

In general, the sodium contents observed are below toxic levels for plants, that is, $0.25-0.50 \%$, respectively, $2500-5000 \mathrm{mg} \mathrm{kg}^{-1}$ of sodium in leaf dry mass (Dias and Blanco, 2010), which means that crop nutrition was not compromised by accumulation of the element detected in the leaf dry mass.

\section{Conclusions}

Phosphate fertilization promoted adequate nutrition for passion fruit plants in terms of $\mathrm{N}, \mathrm{P}, \mathrm{K}, \mathrm{Mg}$ and $\mathrm{S}$, independent of the source provided, but promoted adequate $\mathrm{Ca}$ only for doses up to $36 \mathrm{~g}$ hole $\mathrm{e}^{-1}$ of $\mathrm{P}_{2} \mathrm{O}_{5}$. Additionally, triple superphosphate enhanced the leaf content of $\mathrm{N}$ and $\mathrm{Mg}$ and simple superphosphate $\mathrm{Ca}$ and $\mathrm{S}$.

Except for B, the micronutrient leaf contents were not influenced by $\mathrm{P}_{2} \mathrm{O}_{5}$ doses or sources.

Plants were impaired in $\mathrm{B}, \mathrm{Cu}, \mathrm{Fe}$ and $\mathrm{Mn}$, except for $\mathrm{Fe}$ in those not fertilized with $\mathrm{P}_{2} \mathrm{O}_{5}$ and those treated with 24 and 36 g hole $^{-1}$ of $\mathrm{P}_{2} \mathrm{O}_{5}$ in simple superphosphate form. 
Considering the adequate nutritional status for passion fruit, it is recommended that a fertilization of 36 $\mathrm{g} \mathrm{hole}^{-1}$ year $^{-1}$ of $\mathrm{P}_{2} \mathrm{O}_{5}$ be applied, whether simple or triple superphosphate.

\section{References}

Alvares, C.A., Stape, J.L., Sentelhas, P.C., Gonçalves, J.L.M., Sparovek, G. 2013. Köppen's climate classification map for Brazil. Meteorol. Z. 22, 711-728.

Barbosa, T.M.B., Santos, J.Z.L., Tucci, C.A.F., Silva, S.V., Cardoso, A.A.S., Pereira, B.F.F. 2015. Phosphorus sources: effects on growth and phosphorus fractions of Curauá (Ananas erectifolius L. B. Smith). Commun. Soil Sci. Plant Anal. 46, 12001211.

Bataglia, O.C., Furlani, A.M.C., Teixeira, J.P.F., Furlani, P.R., Gallo, J.R. 1983. Métodos de análise química de plantas. Instituto Agronômico, Campinas, 48 pp. (Boletim Técnico, 78).

Barretti, P.B., Souza, R.M., Aziz, A., Pozza, A., Pozza, E.A., Carvalho, J.G., Souza, J.T. 2008. Aumento da eficiência nutricional de tomateiros inoculados com bactérias endolíticas promotoras de crescimento. Rev. Bras. Ciênc. Solo 32, 1541-1548.

Borges, A.L., Caldas, R.C., Lima, A.A., Almeida, I.E. 2002a. Efeito de doses de NPK sobre os teores de nutrientes nas folhas e no solo, e na produtividade do maracujazeiro amarelo. Rev. Bras. Frutic. 24, 208-213.

Borges, A.L., Raij, B., Van., Magalhães, A.F.J., Bernardi, A.C.C., Lima, A.A. 2002b. Nutrição mineral, calagem e adubação do maracujazeiro irrigado. Embrapa Mandioca e Fruticultura, Cruz das Almas, 8 pp. (Circular Técnica, 50).
Brown, K.R., Courtin, P.J., Negrave, R.W. 2011. Growth, foliar nutrition and $\delta 13 \mathrm{C}$ responses of red alder (Alnus rubra) to phosphorus additions soon after planting on moist sites. For. Ecol. Manage. 262, 791-802.

Brunetto, G., Nava, G., Ambrosini, V.G., Comin, J.J., Kaminski, J. 2015. The pear tree response to phosphorus and potassium fertilization. Rev. Bras. Frutic. 37, 507- 516.

Carvalho, A.J.C., Fontes, P.S.F., Freitas, M.S.M., Monnerat, P.H., Fontes, A.G. 2011. Yellow passion fruit plant nutritional diagnosis at different phenological stages by the diagnosis and Recommendation Integrated System method. J. Plant Nutr. 34, 614-626.

Cavalcante, L.F., Cavalcante, I.H.L., Rodolfo Junior, F.R., Cavalcante, M.Z.B., Santos, G.P. 2012. Leaf-macronutrient status and fruit yield of biofertilized yellow passion plants. J. Plant Nutr. 35, 176-191.

Cerutti, T., Delatorre, C.A. 2013. Nitrogen and phosphorus interaction and cytokinin: Responses of the primary root of Arabidopsis thaliana and the pdr1 mutant. Plant Sci. 198, 91-97.

Dias, N.S., Blanco, F.F. 2010. Efeitos dos sais no solo e na planta In: H. R. Gheyi, N. S. Dias, C. F. Lacerda (ed). Manejo da salinidade na agricultura: Estudos básicos e aplicados, First Edition. Instituto Nacional de Ciência e Tecnologia em Salinidade, Fortaleza, CE, pp. 130-141.

EMBRAPA - Empresa Brasileira de Pesquisa Agropecuária. 2011. Manual de Análises Químicas de Solos, Plantas e Fertilizantes. Embrapa Solos/Embrapa Informação Tecnológica, Brasília, 230 pp.

EMBRAPA - Empresa Brasileira de Pesquisa Agropecuária. 2013. Sistema Brasileiro de Classificação dos Solos. Third Edition. Embrapa Solos, Brasília, 353 pp. 
Ferreira, D.F. 2014. Sisvar: a guide for its bootstrap procedures in multiple comparisons. Ciênc. Agrotec. $38,109-112$.

Kondo, T., Higuchi, H. 2013. Effects of excess phosphorus application on passion fruit quality. Trop. Agr. Develop. 57, 109-113.

Leite, E.M., Diniz, A.A., Cavalcante, L.F., Gheyi, H.R., Campos, V.B. 2010. Redução da sodicidade em solo irrigado com a utilização de ácido sulfúrico e gesso agrícola. Rev. Caatinga. 23, 110-116.

Lemos, V.T., França, A.C., Silva, E.B., Marinho, R.L. S., Franco, M. H.R., Avellar, M., Freitas, A.F., Reis, L.A.C., Corrêa, J.M., Carvalho, G.R. 2015. Ácido cítrico e fósforo no desenvolvimento e estado nutricional de mudas de café. Coffee Sci. 10, 298-308.

Malavolta, E., Vitti, G.C., Oliveira, S.A. 1997. Avaliação do estado nutricional das plantas: princípios e aplicações. Potafós, Piracicaba, 319 pp.

Marschner, P. 2012. Mineral nutrition of higher plants. Third Edition, Elsevier, London, 643 p.

Martínez, O.A, Crowley, D.E, Mora, M.L, Jorquera, M.A. 2015. Short-term study shows that phytatemineralizing rhizobacteria inoculation affects the biomass, phosphorus (P) uptake and rhizosphere properties of cereal plants. J. Soil Sci. Plant Nutr. 15, 153-166.

Meletti, L.M.M. 2011. Avanços na cultura do maracujá no Brasil. Rev. Bras. Frutic. 33, 83-91.

Miyake, R.T.M., Furlaneto, F.P,B., Narita, N., Takata, W.H.S., Creste, J.E. 2016. Economic evaluation of different types of nutritional management in yellow passion fruit vines (Passiflora edulis Sims.). Aust. J. Crop Sci. 10, 1572-1577.

Moreira, R.A., Cruz, M.C.M., Fernandes, D.R., Silva, E.B., Oliveira, J. 2016. Nutrient accumulation at the initial growth of pitaya plants according to phosphorus fertilization. Pesqui. Agropecu. Trop. 46, 230-237.
Neves, O.S.C., Carvalho, J.G., Oliveira, E.V., Neves, V.B.F. 2008. Crescimento, nutrição mineral e nível crítico foliar de $\mathrm{P}$ em mudas de umbuzeiro, em função da adubação fosfatada. Rev. Bras. Frutic. 30, 801-805.

Prado, R.M., Vale, D.W., Romualdo, L.M. 2005. Fósforo na nutrição e produção de mudas de maracujazeiro. Acta Sci. Agron. 27, 493-498.

Ribeiro, A.C., Guimarães, P.T.G., Alvarez, V.V.H. 1999. Recomendações para o uso de corretivos e fertilizantes em Minas Gerais. $5^{\mathrm{a}}$ aproximação. Comissão de Fertilidade do Solo do Estado de Minas Gerais, Viçosa, 359 pp.

Sandaña, P., Pinochet, D. 2016. Phosphorus acquisition of wheat, pea and narrow-leafed lupin under different P supplies. J. Soil Sci. Plant Nutr. 16, 537-549.

Santin, D., Benedetti, E.L., Kaseker, J.F., Bastos, M.C., Reissmann, C.B., Wendling, I., Barros, N.F. 2013. Nutrição e crescimento da erva-mate submetida à calagem. Ciênc. Florest. 23, 55-66.

Santos, G.P., Lima Neto, A.J., Cavalcante, L.F., Cavalcante, Í.H.L., Souto, A.G.L. 2014. Crescimento e produção do maracujazeiro amarelo, sob diferentes fontes e doses de fósforo em cobertura. Biosci. J. 30, 535-533.

Silva, E.M., Melo, N.F., Mendes, A.M.S., Araújo, F.P., Maia, L.C., Yano-Melo, A.M. 2015. Response of Passiflora setacea to mycorrhization and phosphate fertilization in a Semiarid Region of Brazil. J. Plant Nutr. 38, 431-442.

Silva-Matos, R.R.S., Silva Junior, G.B., Marques, A.S., Monteiro, M.L., Cavalcante, Í.H.L., Osajima, J.A. 2016. New organic substrates and boron fertilizing for production of yellow passion fruit seedlings. Arch. Agron. Soil Sci. 62, 445-455.

Sousa, V.F., Folegatti, M.V., Coelho Filho, M.A., Frizzone, J.A. 2002. Distribuição radicular do maracujazeiro sob diferentes doses de potássio 
aplicadas por fertirrigação. Rev. Bras. Eng. Agríc. Ambient. 6, 51-56.

Souza, M.S.M., Bezerra, F.M.L., Viana, T.V.A., Teófilo, E.M., Cavalcante, I.H.L. 2009. Evapotranspiração do maracujá nas condições do Vale do Curu. Rev. Caatinga. 22, 11-16.
Vitorazi Filho, J.A., Lima, K.B., Freitas, M.S.M., Martins, M.A., Olivares, F.L. 2012. Crescimento de mudas de maracujazeiro-doce inoculadas com fungos micorrízicos arbusculares e bactérias diazotróficas sob diferentes doses de fósforo. Rev. Bras. Frutic. 34, 42-450. 